Toxic Substances Hydrology Program

Prepared in cooperation with the

U.S. Army Environmental Command

\title{
Comparison of Pumped and Diffusion Sampling Methods to Monitor Concentrations of Perchlorate and Explosive Compounds in Ground Water, Camp Edwards, Cape Cod, Massachusetts, 2004-05
}

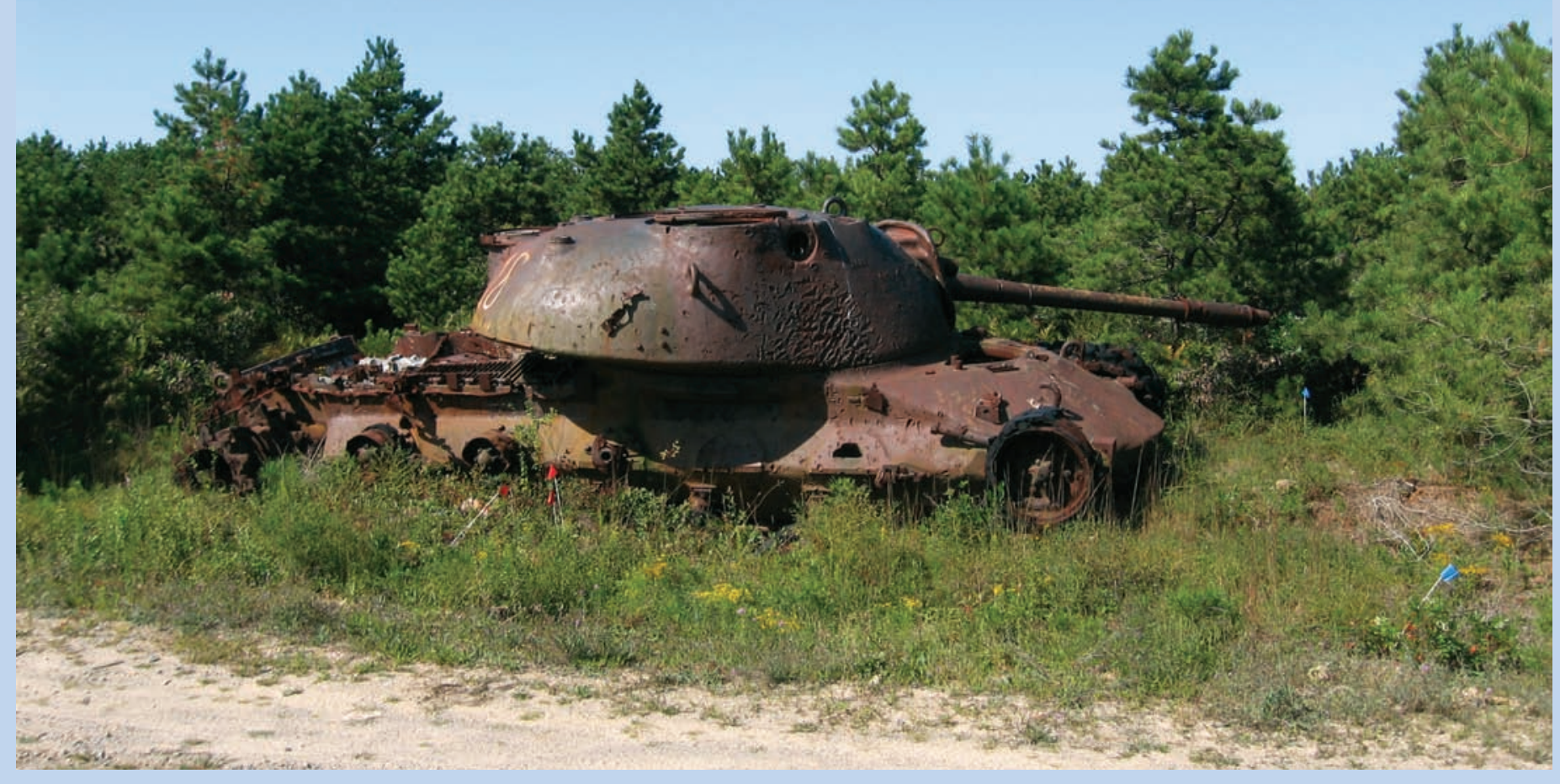

Scientific Investigations Report 2008-5109 
Cover. Photograph shows tank used as a target for artillery practice in the Impact Area, Camp Edwards, Massachusetts Military Reservation, Cape Cod, Massachusetts. (Photograph by Darrin Smith, U.S. Army Corps of Engineers, September 2008) 


\section{Comparison of Pumped and Diffusion Sampling Methods to Monitor Concentrations of Perchlorate and Explosive Compounds in Ground Water, Camp Edwards, Cape Cod, Massachusetts, 2004-05}

By Denis R. LeBlanc and Don A. Vroblesky

Toxic Substances Hydrology Program

Prepared in cooperation with the

U.S. Army Environmental Command

Scientific Investigations Report 2008-5109 


\section{U.S. Department of the Interior DIRK KEMPTHORNE, Secretary}

\section{U.S. Geological Survey \\ Mark D. Myers, Director}

U.S. Geological Survey, Reston, Virginia: 2008

For product and ordering information:

World Wide Web: http://www.usgs.gov/pubprod

Telephone: 1-888-ASK-USGS

For more information on the USGS — the Federal source for science about the Earth, its natural and living resources, natural hazards, and the environment:

World Wide Web: http://www.usgs.gov

Telephone: 1-888-ASK-USGS

Any use of trade, product, or firm names is for descriptive purposes only and does not imply endorsement by the U.S. Government.

Although this report is in the public domain, permission must be secured from the individual copyright owners to reproduce any copyrighted materials contained within this report.

Suggested citation:

LeBlanc, D.R., and Vroblesky, D.A., 2008, Comparison of pumped and diffusion sampling methods to monitor concentrations of perchlorate and explosive compounds in ground water, Camp Edwards, Cape Cod, Massachusetts, 2004-05: U.S. Geological Survey Scientific Investigations Report 2008-5109, 16 p. 


\section{Contents}

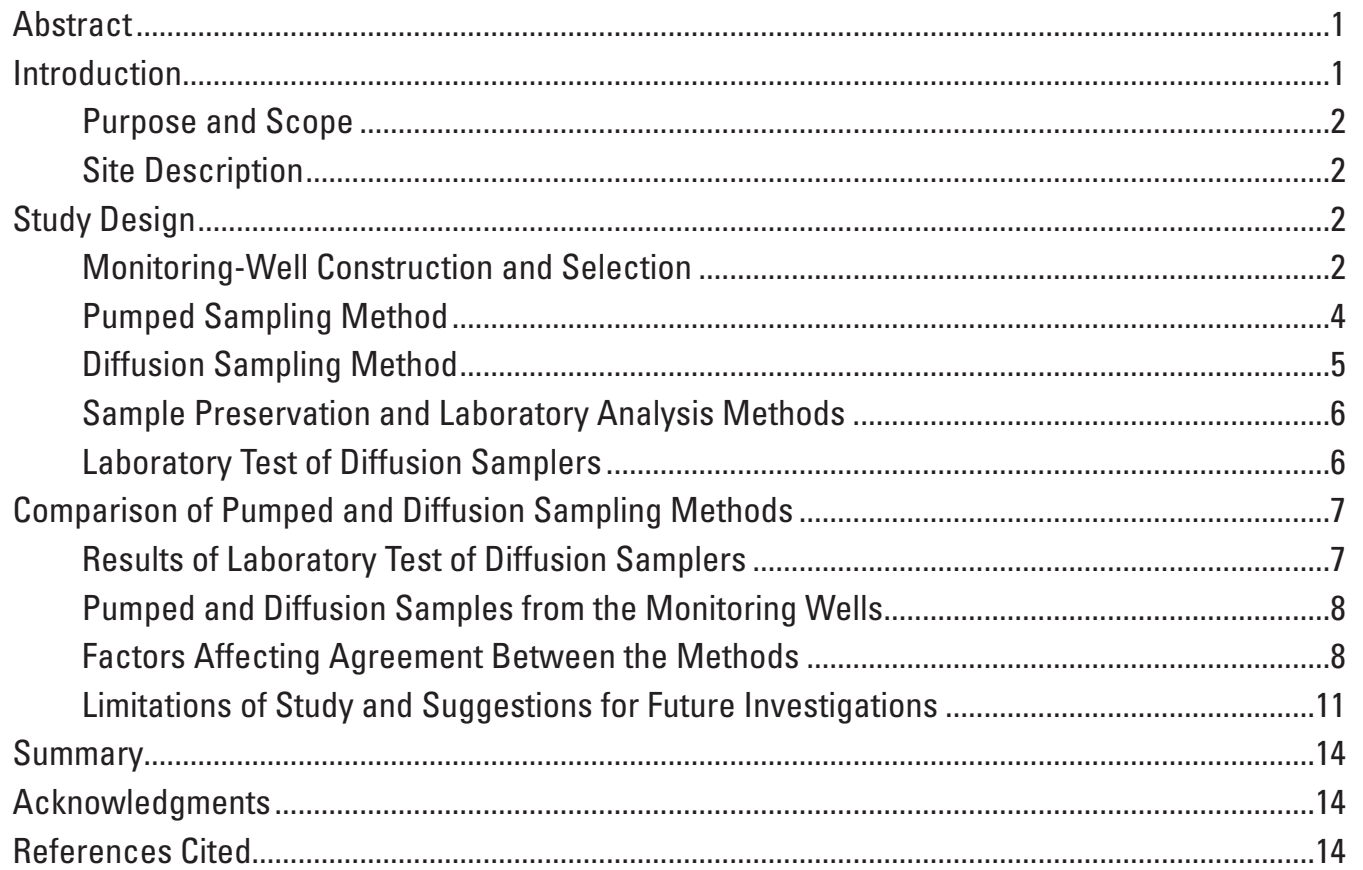

\section{Figures}

1. Map showing location of monitoring wells, water table, plumes of ground-water contamination, and the Impact Area at Camp Edwards on the Massachusetts Military Reservation, Cape Cod, Massachusetts.

2-3. Photographs showing-

2. Diffusion sampler showing rigid, porous polyethylene tubing and slip-on end

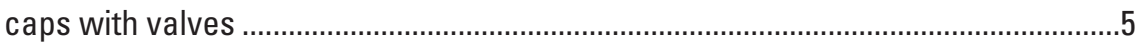

3. Vertical arrangement of diffusion samplers as they are retrieved from a well ........6

4-6. Graphs showing-

4. Comparison of $(A)$ perchlorate, $(B) \operatorname{RDX}$, and $(C) H M X$ concentrations for pumped and diffusion samples collected from 15 wells, including two replicate samples, near the Impact Area at Camp Edwards on the Massachusetts Military Reservation, Cape Cod, Massachusetts, 2005

5. Comparison of perchlorate, RDX, and HMX concentrations for pumped and diffusion samples collected from selected wells near the Impact Area at Camp Edwards on the Massachusetts Military Reservation, Cape Cod, Massachusetts, 2005.

6. Time history of $(A)$ perchlorate, $(B) \mathrm{RDX}$, and $(C) \mathrm{HMX}$ concentrations for pumped and diffusion samples collected from monitoring well MW-165M2 at Camp Edwards on the Massachusetts Military Reservation, Cape Cod, Massachusetts, August 2003 to August 2007 


\section{Tables}

1. Characteristics of monitoring wells used for collection of pumped and diffusion samples at Camp Edwards, Massachusetts Military Reservation, Cape Cod, Massachusetts.

2. Ordnance-related compounds analyzed in pumped and diffusion samples collected from monitoring wells at Camp Edwards, Massachusetts Military Reservation, Cape Cod, Massachusetts, 2004-05

3. Concentrations of perchlorate and explosive compounds in samples from rigid, porous polyethylene diffusion samplers set in carboys containing ground water collected from wells at Camp Edwards, Massachusetts Military Reservation, Cape Cod, Massachusetts, May 2004

4. Installation and collection specifications and concentrations of perchlorate, RDX, HMX, and other explosive compounds in diffusion and pumped samples collected from monitoring wells at Camp Edwards, Massachusetts Military Reservation, Cape Cod, Massachusetts, November 2004-August 2005.

\section{Conversion Factors, Datums, and Abbreviations}

\begin{tabular}{|c|c|c|}
\hline Multiply & By & To obtain \\
\hline \multicolumn{3}{|c|}{ Length } \\
\hline inch (in.) & 2.54 & centimeter $(\mathrm{cm})$ \\
\hline inch (in.) & 25.4 & millimeter (mm) \\
\hline inch (in.) & 25,400 & micrometer $(\mu \mathrm{m})$ \\
\hline foot (ft) & 0.3048 & meter $(\mathrm{m})$ \\
\hline mile (mi) & 1.609 & kilometer $(\mathrm{km})$ \\
\hline \multicolumn{3}{|c|}{ Area } \\
\hline acre & 0.4047 & hectare (ha) \\
\hline \multicolumn{3}{|c|}{ Volume } \\
\hline gallon (gal) & 3.785 & liter $(\mathrm{L})$ \\
\hline quart (qt) & 946.4 & milliliter $(\mathrm{mL})$ \\
\hline \multicolumn{3}{|c|}{ Flow rate } \\
\hline foot per day $(\mathrm{ft} / \mathrm{d})$ & 0.3048 & meter per day $(\mathrm{m} / \mathrm{d})$ \\
\hline inch per year (in/yr) & 25.4 & millimeter per year $(\mathrm{mm} / \mathrm{yr})$ \\
\hline \multicolumn{3}{|c|}{ Mass } \\
\hline ounce, avoirdupois (oz) & 28.35 & $\operatorname{gram}(\mathrm{g})$ \\
\hline
\end{tabular}

Temperature in degrees Celsius $\left({ }^{\circ} \mathrm{C}\right)$ may be converted to degrees Fahrenheit $\left({ }^{\circ} \mathrm{F}\right)$ as follows:

$$
{ }^{\circ} \mathrm{F}=\left(1.8 \times{ }^{\circ} \mathrm{C}\right)+32
$$

Vertical coordinate information is referenced to the National Geodetic Vertical Datum of 1929 (NGVD 29).

Horizontal coordinate information is referenced to the North American Datum of 1983 (NAD 83).

Altitude, as used in this report, refers to distance above the vertical datum.

Concentrations of chemical constituents in water are given either in milligrams per liter (mg/L) or micrograms per liter ( $\mu \mathrm{g} / \mathrm{L})$. 


ABBREVIATIONS
$\begin{array}{ll}\text { AFCEE } & \text { Air Force Center for Engineering and the Environment } \\ \text { HMX } & \text { octahydro-1,3,5,7-tetranitro-1,3,5,7-tetrazocine } \\ \text { IAGWSP } & \text { Impact Area Groundwater Study Program } \\ \text { IRP } & \text { Installation Restoration Program } \\ \text { MMR } & \text { Massachusetts Military Reservation } \\ \text { PCE } & \text { tetrachloroethene } \\ \text { PVC } & \text { polyvinyl chloride } \\ \text { RDX } & \text { hexahydro-1,3,5-trinitro-1,3,5-triazine } \\ \text { TCE } & \text { trichloroethene } \\ \text { USAEC } & \text { U.S. Army Environmental Command } \\ \text { USEPA } & \text { U.S. Environmental Protection Agency } \\ \text { USGS } & \text { U.S. Geological Survey } \\ \text { VOC } & \text { volatile organic compound }\end{array}$


THIS PAGE INTENTIONALLY LEFT BLANK 


\title{
Comparison of Pumped and Diffusion Sampling Methods to Monitor Concentrations of Perchlorate and Explosive Compounds in Ground Water, Camp Edwards, Cape Cod, Massachusetts, 2004-05
}

\author{
By Denis R. LeBlanc and Don A. Vroblesky
}

\begin{abstract}
Laboratory and field tests were conducted at Camp Edwards on the Massachusetts Military Reservation on Cape Cod to examine the utility of passive diffusion sampling for long-term monitoring of concentrations of perchlorate and explosive compounds in ground water. The diffusion samplers were constructed of 1-inch-diameter rigid, porous polyethylene tubing. The results of laboratory tests in which diffusion samplers were submerged in containers filled with ground water containing perchlorate, RDX (hexahydro1,3,5-trinitro-1,3,5-triazine), and HMX (octahydro-1,3,5,7tetranitro-1,3,5,7-tetrazocine) indicate that concentrations inside the diffusion samplers equilibrated with concentrations in the containers within the 19-day-long test period. Field tests of the diffusion samplers were conducted in 15 wells constructed of 2- or 2.5-inch-diameter polyvinyl chloride pipe with 10-foot-long slotted screens. Concentrations of perchlorate, RDX, and HMX in the diffusion samplers placed in the wells for 42 to 52 days were compared to concentrations in samples collected by low-flow pumped sampling from 53 days before to 109 days after retrieval of the diffusion samples. The results of the field tests indicate generally good agreement between the pumped and diffusion samples for concentrations of perchlorate, RDX, and HMX. The concentration differences indicate no systematic bias related to contaminant type or concentration levels.
\end{abstract}

\section{Introduction}

Long-term monitoring of water quality is an important part of ground-water remediation. During most remediation projects, many monitoring wells are installed to determine the spatial distribution of contaminants and to obtain hydrogeologic information needed to design the remediation approach. Once the approach is implemented, monitoring changes in water quality may continue for many years. The success of a monitoring program generally requires frequent sampling of many sites to discern temporal and spatial trends in contaminant concentrations and to obtain evidence of natural and enhanced attenuation of contaminant levels (National Research Council, 2000; Sara, 2006; Wiedemeier and others, 2006). Therefore, the cost of long-term monitoring can be a substantial part of the cost of a remediation program. Common methods for collecting water samples from monitoring wells include purging with a submersible pump that is set in the well and lifts the water to the surface, and purging with a suction pump that draws the water to the surface by suction through a sampling tube. These pumped sampling methods can involve the use of heavy or cumbersome pump reels, generators, and gas cylinders; require two or more people to operate the equipment safely; and necessitate disposal of water purged from the well prior to sample collection (U.S. Army Environmental Command, 2007a; Nielsen and Nielsen, 2006). Passive diffusion sampling is a low-cost alternative to pumped sampling in many situations (Vroblesky and Hyde, 1997; Interstate Technology \& Regulatory Council, 2008). In the passive diffusion sampling method, a diffusion chamber filled with an appropriate fluid, usually water free of the contaminants of interest, is set in the well screen for a sufficient duration before retrieval to allow concentrations in the sampler and well screen to reach an equilibrium by diffusion across the membrane of the sampler (Vroblesky, 2001a). Installation and retrieval can commonly be done by one person using minimal equipment, and no purge water is produced.

The use of passive diffusion samplers to monitor concentrations of volatile organic compounds (VOCs) has been widely documented (Vroblesky and Hyde, 1997; Church, 2000; Savoie and others, 2000; Vroblesky, 2001b; Archfield and LeBlanc, 2005; Interstate Technology \& Regulatory Council, 2008). The diffusion membranes of samplers used to monitor VOCs typically are made from low-density polyethylene bags or lay-flat tubing (Vroblesky, 2001a). Many contaminants of interest, such as inorganic species, cannot diffuse through the low-density polyethylene membrane, however, so other membranes have been proposed for use in 
passive diffusion samplers, including regenerated-cellulose dialysis membranes (Vroblesky and others, 2002; LeBlanc, 2003; Ehlke and others, 2004); nylon mesh (Vroblesky and others, 2002; Vroblesky and others, 2003); rigid, porous polyethylene tubing (Parsons, 2005); and perforated tubing (Vroblesky and Casey, 2007).

Passive diffusion sampling is used at the Massachusetts Military Reservation (MMR) on Cape Cod to monitor concentrations of VOCs in a glacial sand and gravel aquifer (Archfield and LeBlanc, 2005; Air Force Center for Environmental Excellence, 2005). The VOCs are present in 12 contaminant plumes that extend as far as $3 \mathrm{mi}$ from the reservation; originate from historical sources such as aircraft maintenance, fuel use, and fire-training areas; and are presently (2008) the focus of a major remediation effort (Air Force Center for Engineering and the Environment, 2007).

The sand and gravel aquifer also contains 11 plumes of perchlorate and explosive compounds from historical testing, use, and disposal of military munitions at Camp Edwards on the MMR (fig. 1). The plumes are present mostly in the northern part of the MMR in an area referred to as the Impact Area. These plumes also are the subject of a major remediation effort (U.S. Army Environmental Command, 2007b) that includes the drilling and regular sampling of many monitoring wells. There is a concern that the monitoring program, which involves repeated visits to wells with vehicles and equipment, detrimentally affects the restoration and preservation of ecological habitats in the northern 14,000 acres of the MMR, which are managed jointly as the Upper Cape Cod Groundwater Reserve by the Massachusetts National Guard and the state's environmental agencies (Massachusetts National Guard, 2008a). Therefore, there is an interest in whether passive diffusion sampling methods can be used for the long-term monitoring of concentrations of perchlorate and explosive compounds at Camp Edwards.

\section{Purpose and Scope}

This report evaluates the results of laboratory and field tests of rigid, porous polyethylene diffusion samplers for monitoring concentrations of perchlorate and explosive compounds in ground water at Camp Edwards. The field tests were conducted near the Impact Area in 15 monitoring wells typical of the monitoring wells at the MMR known to contain various levels of these contaminants. Ground-water samples were collected from the 15 wells in 2005 by both pumped and diffusion sampling methods. The results presented in this report are intended for use in evaluating whether passive diffusion sampling is a useful alternative for long-term monitoring at the site. This study was done cooperatively by the Toxic Substances Hydrology Program of the U.S. Geological Survey (USGS) and the Impact Area Groundwater Study Program (IAGWSP) of the U.S. Army Environmental Command (USAEC).

\section{Site Description}

The study was conducted in the shallow unconfined aquifer that underlies the western part of Cape Cod (fig. 1). The aquifer is composed of sand and gravel, with some silt and clay, which were deposited near the end of the Pleistocene Epoch, 15,000 to 16,000 years ago (Oldale, 1992; Walter and Masterson, 2003). In the study area, the sand and gravel aquifer is about 200 to $300 \mathrm{ft}$ thick and overlies crystalline bedrock. The only source of water to the aquifer is about $27 \mathrm{in} / \mathrm{yr}$ of recharge from precipitation. The water table of western Cape Cod forms a mound with its highest point on the eastern side of the MMR (fig. 1). Ground water flows radially outward from the top of the mound at a rate of 1 to $2 \mathrm{ft} / \mathrm{d}$ toward discharge areas at streams, ponds, coastal wetlands, and the ocean (LeBlanc and others, 1986; Walter and Whealan, 2005).

The MMR has been used for military purposes since the early 1900s. The reservation was home to Camp Edwards during World War II and Otis Air Force Base during the Cold War. Since about 1973, the Massachusetts National Guard's Training Site Camp Edwards, Otis Air National Guard Base, and Coast Guard Air Station Cape Cod have been the major tenants on the MMR (Massachusetts National Guard, 2008b). Two environmental programs - the Installation Restoration Program (IRP) and the IAGWSP - are presently (2008) addressing ground-water contamination from the historical military activities at the MMR.

\section{Study Design}

The study included several rounds of field tests of the rigid, porous polyethylene diffusion samplers in wells near the Impact Area. The wells were installed by the IAGWSP during earlier investigations. The field tests included collection of water samples by pumped and diffusion sampling methods and laboratory analysis of the samples for concentrations of perchlorate and explosive compounds. The field tests were preceded by a laboratory test of the diffusion samplers in which the samplers were immersed in water collected from wells known to contain ordnance-related compounds.

\section{Monitoring-Well Construction and Selection}

The monitoring wells used in this study are sampled regularly by the IAGWSP. The selected wells (fig. 1 and table 1) are known from historical data to contain a range of concentrations of the contaminants of interest, primarily perchlorate, RDX (hexahydro-1,3,5-trinitro-1,3,5-triazine), and HMX (octahydro-1,3,5,7-tetranitro-1,3,5,7-tetrazocine). The wells were already scheduled for sampling by pumped methods during the time period of this study; thus, the cost of collecting and analyzing pumped samples solely for this study was obviated. 


\section{EXPLANATION}

Areal extent of plumes of ground-water contamination, 2007

$\ulcorner\neg$ Boundary of Massachusetts Military Reservation

I Boundary of Impact Area
-55 - Water-table contour - altitude of water table. Contour interval is 5 feet. Datum is NGVD 29

$\longleftarrow$ Direction of ground-water flow MW-39M2

- Monitoring well-with identifier
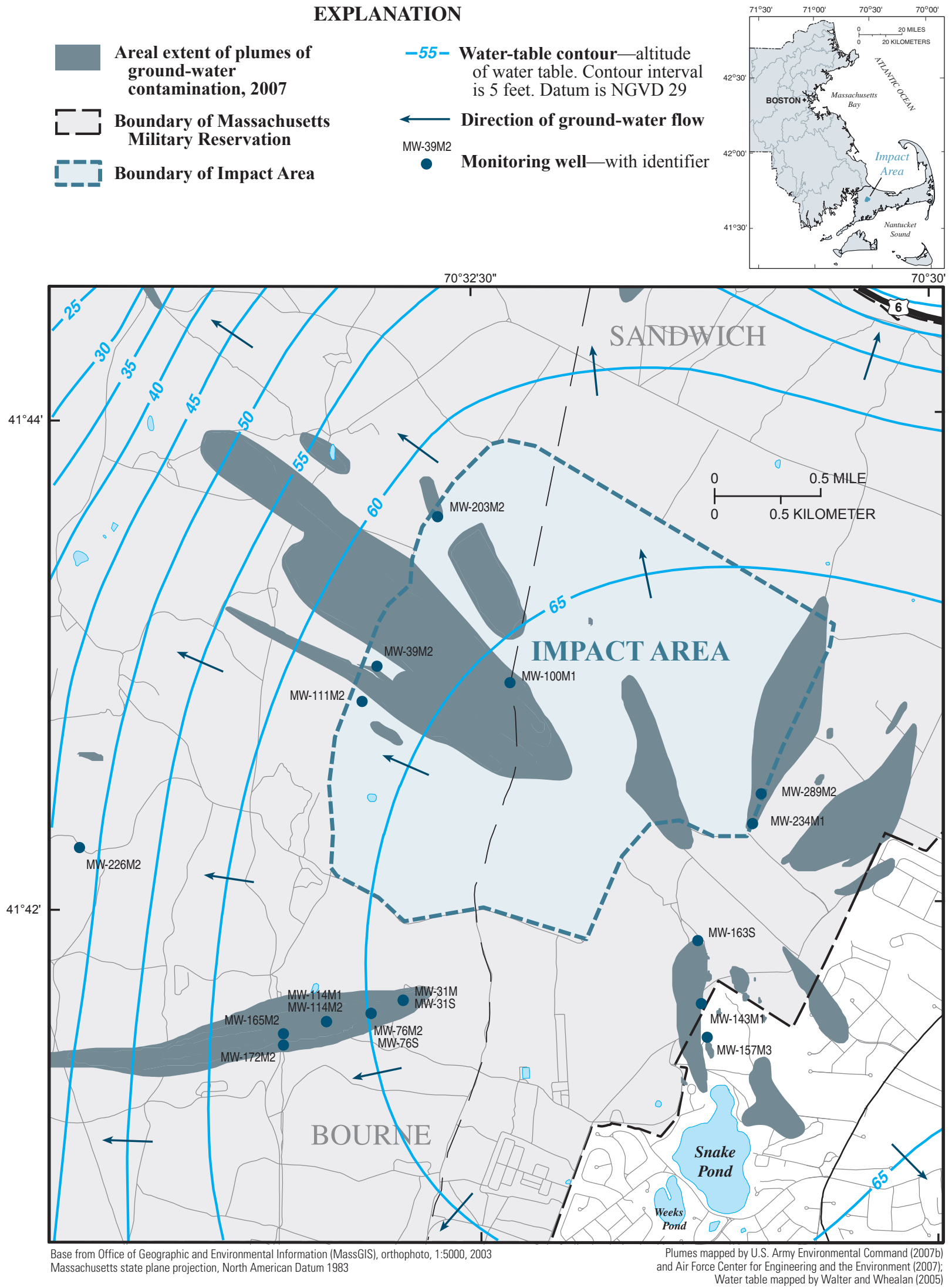

Figure 1. Location of monitoring wells, water table, plumes of ground-water contamination, and the Impact Area at Camp Edwards on the Massachusetts Military Reservation, Cape Cod, Massachusetts. 
Table 1. Characteristics of monitoring wells used for collection of pumped and diffusion samples at Camp Edwards, Massachusetts Military Reservation, Cape Cod, Massachusetts. Well locations shown in figure 1.

[Source of data: Impact Area Groundwater Study Program (IAGWSP) Environmental Data Management System (EDMS). Altitude in feet relative to National Geodetic Vertical Datum of 1929 (NGVD 29). Location in meters relative to North American Datum of 1983 (NAD 83). m, meter; ft, foot; in., inch]

\begin{tabular}{lcccccccc}
\hline $\begin{array}{c}\text { IAGWSP } \\
\text { well name }\end{array}$ & $\begin{array}{c}\text { X-coordinate } \\
\text { east NAD 83 } \\
\text { (m) }\end{array}$ & $\begin{array}{c}\text { Y-coordinate } \\
\text { north NAD 83 } \\
(\mathbf{m})\end{array}$ & $\begin{array}{c}\text { Altitude of } \\
\text { land surface } \\
\text { (ft) }\end{array}$ & $\begin{array}{c}\text { Altitude of } \\
\text { top of screen } \\
\text { (ft) }\end{array}$ & $\begin{array}{c}\text { Altitude of } \\
\text { bottom of } \\
\text { screen } \\
\text { (ft) }\end{array}$ & $\begin{array}{c}\text { Water- } \\
\text { level date }\end{array}$ & $\begin{array}{c}\text { Altitude of } \\
\text { water level } \\
\text { (ft) }\end{array}$ & $\begin{array}{c}\text { Diameter of } \\
\text { well casing } \\
\text { (in.) }\end{array}$ \\
\hline MW-100M1 & 280014.064 & 829891.049 & 200.92 & 21.92 & 11.92 & $6 / 27 / 2005$ & 65.88 & 2.5 \\
MW-111M2 & 278895.250 & 829748.877 & 198.07 & 16.07 & 6.07 & $6 / 27 / 2005$ & 62.86 & 2.5 \\
MW-114M1 & 278624.895 & 827326.319 & 146.73 & -30.27 & -40.27 & $4 / 26 / 2005$ & 63.79 & 2.5 \\
MW-114M2 & 278624.892 & 827325.708 & 146.73 & 26.73 & 16.73 & $4 / 26 / 2005$ & 63.80 & 2.5 \\
MW-143M1 & 281463.009 & 827463.085 & 101.83 & -42.17 & -52.17 & $6 / 27 / 2005$ & 69.75 & 2.5 \\
& & & & & & & & \\
MW-157M3 & 281506.605 & 827207.673 & 81.80 & 11.80 & 1.80 & $6 / 27 / 2005$ & 70.00 & 2.5 \\
MW-163S & 281435.757 & 827938.391 & 109.15 & 71.15 & 61.15 & $5 / 11 / 2004$ & 68.66 & 2.5 \\
MW-165M2 & 278299.704 & 827235.262 & 143.15 & 18.65 & 8.65 & $4 / 26 / 2005$ & 62.77 & 2.0 \\
MW-172M2 & 278298.909 & 827149.926 & 128.08 & -40.92 & -50.92 & $4 / 26 / 2005$ & 62.72 & 2.0 \\
MW-203M2 & 279468.281 & 831146.038 & 204.37 & 28.37 & 18.37 & $6 / 27 / 2005$ & 60.34 & 2.5 \\
& & & & & & & & 2.5 \\
MW-226M2 & 276758.007 & 828642.881 & 164.18 & -10.82 & -20.82 & $6 / 27 / 2005$ & 53.82 & 2.0 \\
MW-234M1 & 281851.990 & 828824.384 & 173.91 & 43.91 & 33.91 & $5 / 12 / 2004$ & 68.19 & 2.5 \\
MW-289M2 & 281917.110 & 829049.263 & 169.18 & 7.16 & -2.84 & $6 / 27 / 2005$ & 69.51 & 2.5 \\
MW-31M & 279206.575 & 827488.120 & 153.59 & 40.59 & 30.59 & $6 / 27 / 2005$ & 66.60 & 2.5 \\
MW-31S & 279206.575 & 827488.430 & 153.59 & 55.59 & 50.59 & $5 / 11 / 2004$ & 64.98 & 2.0 \\
& & & & & & & & 2.0 \\
MW-39M2 & 279006.632 & 830016.878 & 201.63 & 26.63 & 16.63 & $6 / 27 / 2005$ & 62.55 & 2.0 \\
MW-76M2 & 278963.550 & 827388.991 & 136.06 & 31.06 & 21.06 & $4 / 26 / 2005$ & 64.46 & 2.0 \\
MW-76S & 278963.558 & 827388.380 & 136.06 & 51.06 & 41.06 & $4 / 26 / 2005$ & 64.47 & 2.0 \\
\hline
\end{tabular}

The wells are constructed of 2.0- or 2.5-in.-diameter polyvinyl chloride (PVC) pipe and are finished with slotted PVC screens that are $10 \mathrm{ft}$ long (with the exception of a 5-ft-long screen for well MW-31S, which was used only as a source of water for the laboratory test) (table 1). The length of the standing water columns in the wells used for the diffusion-sampler field tests ranged from about 23 to $122 \mathrm{ft}$. The wells were installed by hollow-stem auger, dual-casing air rotary, and sonic drilling methods according to the protocols described in U.S. Army Environmental Command (2007a).

\section{Pumped Sampling Method}

Water samples were collected from the monitoring wells by contractors for the IAGWSP by positive-displacement pumping methods according to sampling protocols in U.S.
Environmental Protection Agency (USEPA) (1996). The wells used for this study were fitted quasi-permanently with dedicated air-bladder pumps and Teflon-lined 3/8-in.diameter polyethylene discharge tubing. The pump intakes generally were set near the middle of the screened interval. Approximately 6 to 8 gallons of water were pumped to waste prior to sample collection to ensure that field water-quality parameters had stabilized and formation water was sampled. The methods used to collect and preserve the water samples are described in U.S. Army Environmental Command (2007a).

The pumps had to be removed temporarily from the wells during the field tests of the diffusion samplers. Therefore, the pumped samples had to be collected before the diffusion samplers were set in the wells or after they were retrieved. The interval between collection of the pumped and diffusion samples ranged from 0 to 109 days. 


\section{Diffusion Sampling Method}

The passive diffusion samplers used in this study were constructed of rigid, porous polyethylene tubing (fig. 2) similar to the aeration tubing used in fish aquariums. The tubing had an outside diameter of $1.5 \mathrm{in}$., was about $7 \mathrm{in}$. long, and had a pore size of 6 to $15 \mu \mathrm{m}$. Tubing sections longer than 7 in. could not be used because water would leak spontaneously through the tubing walls under pressure heads greater than those that could be counteracted by the capillary suction head in the pores. The ends of the tubing were sealed with polyethylene slip-on caps fitted with stopcock syringe valves with Luer connections. The entire assembly for each diffusion sampler was enclosed in a flexible openmesh polyethylene sleeve (fig. 3) for protection and ease of deployment and retrieval.

The samplers were prepared in advance by capping one end, filling the tubing with distilled, deionized water, capping the other end, submerging the sampler in a container of the water, and forcing air from the pores of the tubing with a syringe attached to one of the valves. The samplers were stored submerged in the container until they were installed in the wells. Each sampler contained about $160 \mathrm{~mL}$ of distilled, deionized water.
The samplers were set in the wells by fastening them to braided polypropylene twine using plastic cable ties passed through the polyethylene mesh and loops tied in the twine at predetermined locations. The bottom end of the twine was tied to a 1-in.-diameter, 7-in.-long, stainless-steel weight to counteract the slight buoyancy of the twine and sampler materials. The top end of the twine was tied to a rubber stopper that fit tightly into the top of the well casing so that the samplers were suspended at the desired points within the screened interval of the wells.

To obtain a detection limit sufficient for this study, about $500 \mathrm{~mL}$ and $100 \mathrm{~mL}$ of water sample were needed for the analysis of explosive compounds and perchlorate, respectively. To obtain this sample volume, four samplers were suspended in each well for periods of 42 to 52 days (fig. 3). Immediately upon retrieval, the samplers were extracted from the polyethylene mesh and wrapped tightly in polyethylene wrap to limit leakage through the tubing walls. Then, water from the four samplers was decanted into a 1-L amber glass bottle for explosive-compound analysis and mixed by gentle swirling. Finally, about $100 \mathrm{~mL}$ were decanted from the 1-L glass bottle into a $125-\mathrm{mL}$ polyethylene bottle for perchlorate analysis.

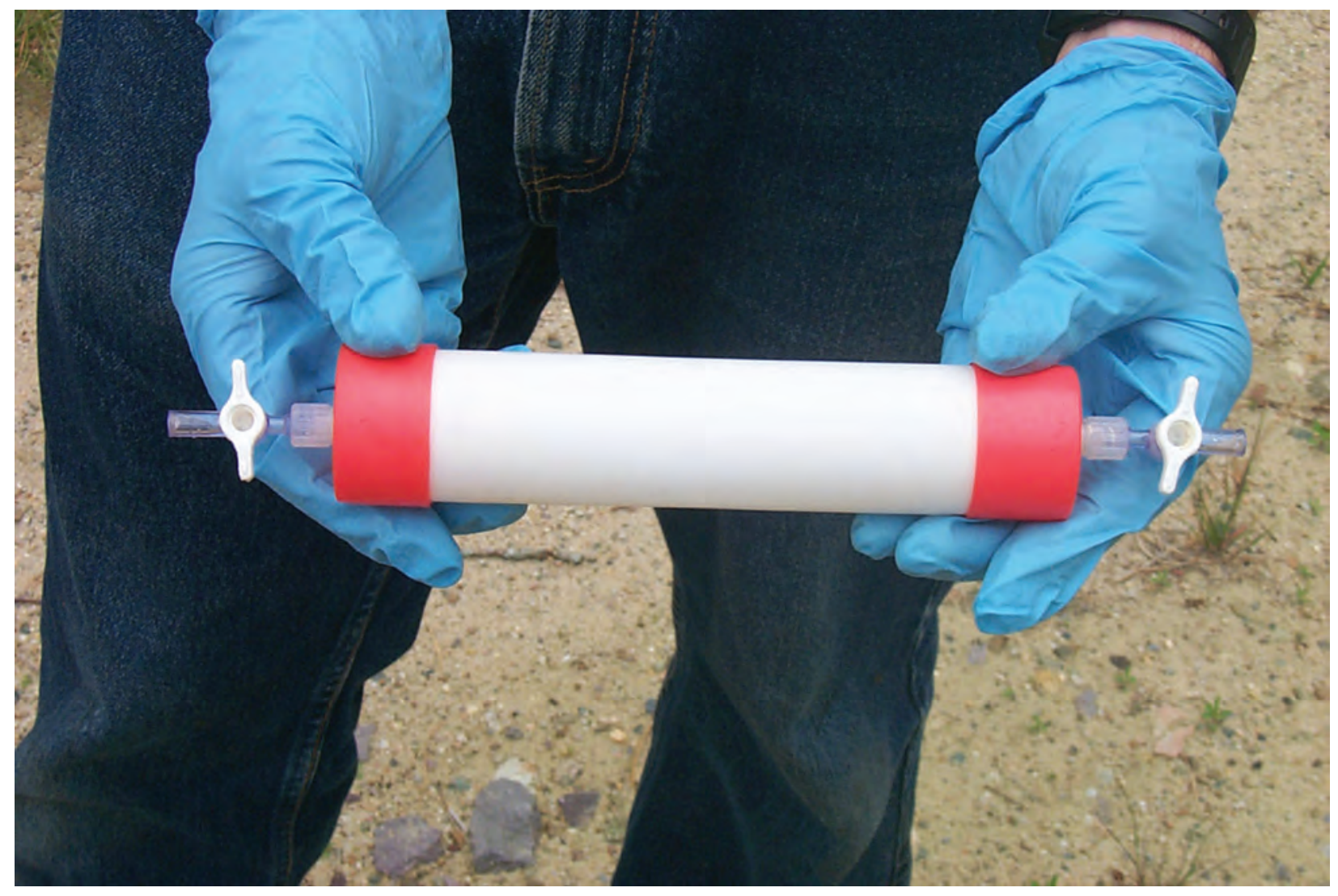

Figure 2. Diffusion sampler showing rigid, porous polyethylene tubing and slip-on end caps with valves. 


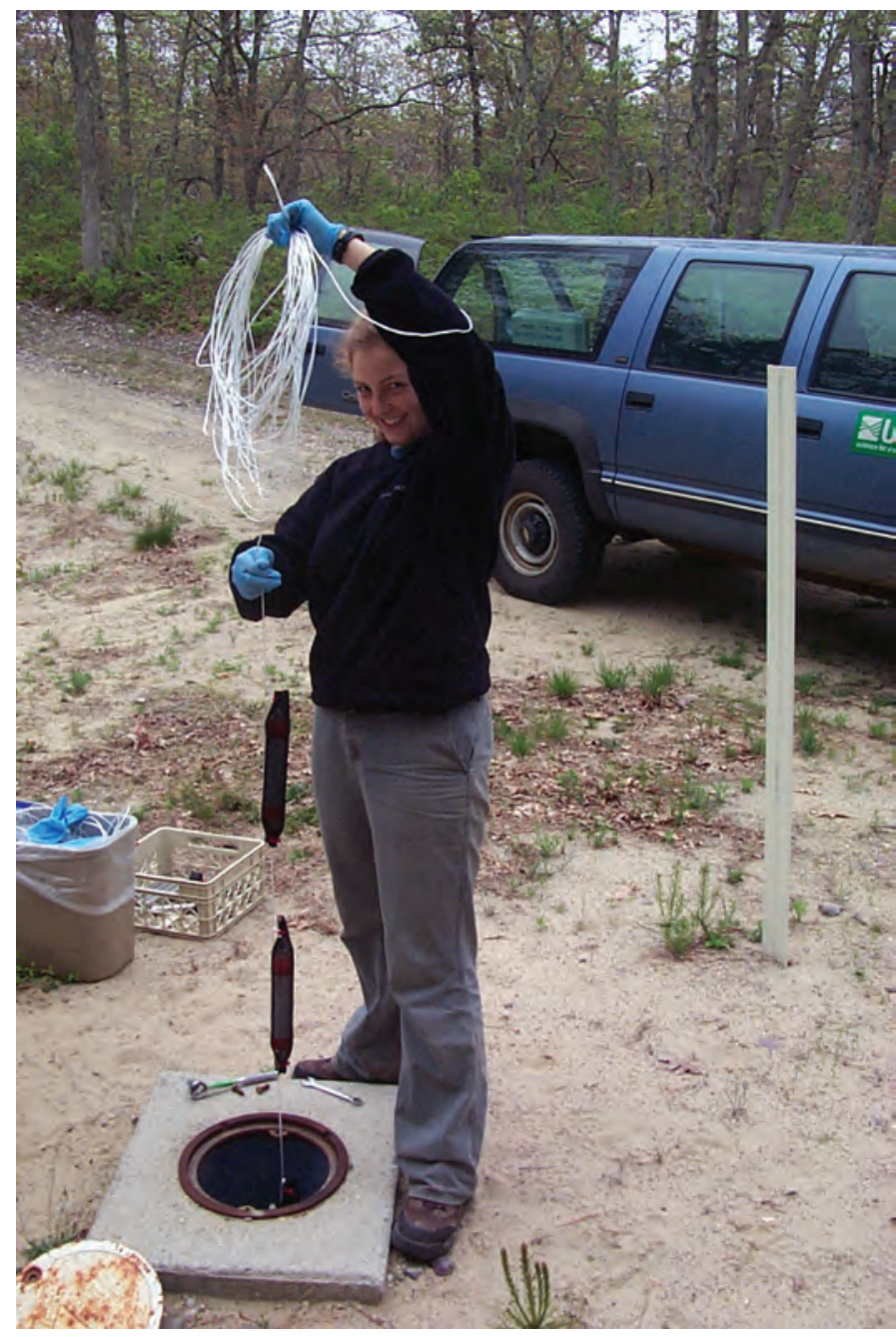

Figure 3. Vertical arrangement of diffusion samplers as they are retrieved from a well. Note flexible polyethylene mesh enclosing each diffusion sampler.

\section{Sample Preservation and Laboratory Analysis Methods}

Water samples for analysis of the explosive compounds were collected in 1-L amber glass bottles, chilled immediately, and stored chilled and in the dark until analysis. Samples for analysis of perchlorate were collected in 125-mL polyethylene bottles and stored in the dark at room temperature until analysis.

The samples were analyzed for 20 compounds (table 2 ). The explosive compounds were analyzed by a modification of USEPA method 8330 (U.S. Environmental Protection Agency, 1994). Perchlorate was analyzed by USEPA method 314.0 (U.S. Environmental Protection Agency, 1999). The pumped samples were analyzed by laboratories under contract to the
IAGWSP; the reporting limits ranged from 0.25 to $10 \mu \mathrm{g} / \mathrm{L}$ (table 2). The diffusion samples were analyzed by Severn Trent Laboratories; the reporting limits for the diffusion samples were similar to those shown in table 2.

\section{Laboratory Test of Diffusion Samplers}

The diffusion-sampler design was tested in the laboratory prior to deployment of the diffusion samplers in the field to verify that diffusion of the perchlorate and explosive compounds through the rigid, porous polyethylene tubing would result in concentrations in the sampler that approximately

Table 2. Ordnance-related compounds analyzed in pumped and diffusion samples collected from monitoring wells at Camp Edwards, Massachusetts Military Reservation, Cape Cod, Massachusetts, 2004-05.

[Reporting limits are shown for the pumped samples. USEPA, U.S. Environmental Protection Agency; RDX, hexahydro-1,3,5-trinitro-1,3,5-triazine; HMX, octahydro-1,3,5,7-tetranitro-1,3,5,7-tetrazocine; MMR, Massachusetts Military Reservation; PETN, Pentaerythriotol tetranitrate; $\mu \mathrm{g} / \mathrm{L}$, microgram per liter]

\begin{tabular}{|c|c|c|}
\hline Method & Analyte & $\begin{array}{c}\text { Reporting } \\
\text { limit } \\
(\mu \mathrm{g} / \mathrm{L})\end{array}$ \\
\hline USEPA 314.0 & Perchlorate & 1.0 \\
\hline \multirow[t]{14}{*}{ USEPA 8330 explosives } & RDX & 0.25 \\
\hline & HMX & 0.25 \\
\hline & 1,3,5-trinitrobenzene & 0.25 \\
\hline & 1,3-dinitrobenzene & 0.25 \\
\hline & Tetryl & 0.25 \\
\hline & Nitrobenzene & 0.25 \\
\hline & 2,4,6-trinitrotoluene & 0.25 \\
\hline & 4-amino-2,6-dinitrotoluene & 0.25 \\
\hline & 2-amino-4,6-dinitrotoluene & 0.25 \\
\hline & 2,6-dinitrotoluene & 0.25 \\
\hline & 2,4-dinitrotoluene & 0.25 \\
\hline & 2-nitrotoluene & 0.25 \\
\hline & 3-nitrotoluene & 0.25 \\
\hline & 4-nitrotoluene & 0.25 \\
\hline \multirow[t]{5}{*}{ MMR-specific explosives } & 2,6-diamino-4-nitrotoluene & 0.5 \\
\hline & 2,4-diamino-6-nitrotoluene & 0.25 \\
\hline & Picric acid & 0.25 \\
\hline & Nitroglycerin & 5 \\
\hline & PETN & 10 \\
\hline
\end{tabular}


equaled those in the surrounding ground water. The diffusion samplers were prepared according to the methods described above, except that they were not enclosed in the flexible polyethylene mesh. The samplers were submerged in eight 2.5 -gal polyethylene carboys that were stored in the dark at $4^{\circ} \mathrm{C}$ for 19 days. Two carboys were filled with distilled, deionized water. The other three pairs of carboys were filled with ground water collected by the IAGWSP from three monitoring wells (MW-163S, MW-234M1, and MW-31S, fig. 1) known to contain a range of concentrations of perchlorate and RDX typical of the plumes on the MMR.

The carboys were gently shaken about every 4 days during the equilibration period. At the end of the 19-day period, the diffusion samplers were removed from the carboys and decanted into the appropriate sample containers as described above. Water from the diffusion samplers in the matched pairs of carboys was blended to obtain a sufficient sample volume. Water samples also were collected from the carboys and preserved in the same manner. The water samples collected from the diffusion samplers and carboys at the end of the test were analyzed for concentrations of perchlorate and explosive compounds as described above, except that perchlorate was analyzed by using USEPA method 8321A (U.S. Environmental Protection Agency, 2007) to obtain a lower detection limit than that for USEPA method 314.0.

\section{Comparison of Pumped and Diffusion Sampling Methods}

The comparison of pumped and diffusion sampling methods includes the preliminary laboratory test of the diffusion samplers and several rounds of field tests in selected monitoring wells at Camp Edwards. The laboratory test was conducted to confirm that perchlorate and explosive compounds diffuse through the porous polyethylene tubing. The field tests were conducted to determine whether diffusion sampling is a useful method for monitoring these contaminants in wells on the MMR.

\section{Results of Laboratory Test of Diffusion Samplers}

The concentrations of the major contaminants of interest - perchlorate, RDX, and HMX - in the water collected from the diffusion samplers and carboys were in close agreement at the end of the 19-day equilibration period of the laboratory test (table 3). The concentrations of several other explosive compounds (2-amino-4,6-dinitrotoluene; 4-amino2,6-dinitrotoluene; and 2,4,6-trinitrotoluene) in the diffusion and carboy samples also agreed reasonably well. Only the compounds detected in at least one sample are shown in table 3 .

Table 3. Concentrations of perchlorate and explosive compounds in samples from rigid, porous polyethylene diffusion samplers set in carboys containing ground water collected from wells at Camp Edwards, Massachusetts Military Reservation, Cape Cod, Massachusetts, May 2004.

[Analysis by Severn Trent Laboratories. Ground-water samples collected by AMEC Earth \& Environmental, Inc. RDX, hexahydro-1,3,5-trinitro-1,3,5-triazine; HMX, octahydro-1,3,5,7-tetranitro-1,3,5,7-tetrazocine; DIFF, sample from diffusion sampler; CRBY, sample from carboy at end of experiment; DIBLANK, carboy filled with distilled, deionized water; $\mu \mathrm{g} / \mathrm{L}$, microgram per liter; J, estimated value; <, value less than reporting limit shown]

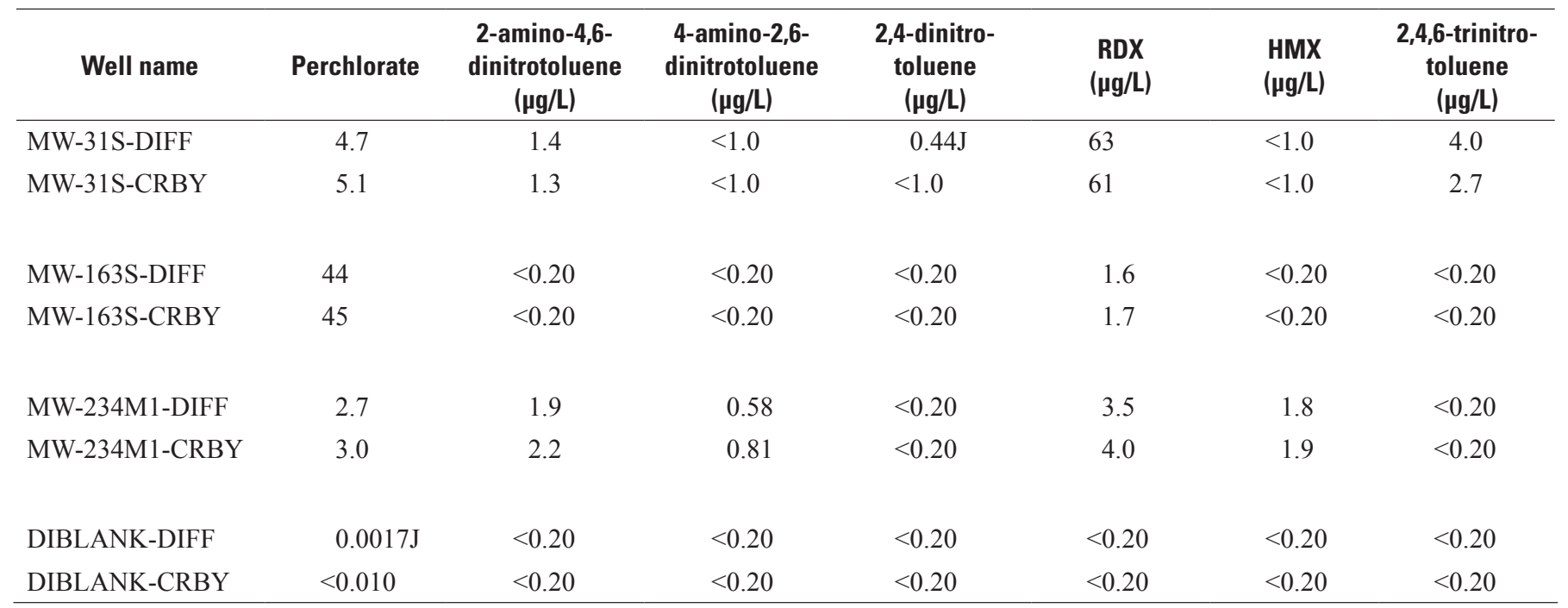


The close agreement indicated that the 19-day period was sufficiently long for concentrations inside the diffusion samplers to equilibrate with concentrations in the surrounding water. Except for the very low estimated concentration of perchlorate $(0.0017 \mu \mathrm{g} / \mathrm{L})$ in the diffusion sampler set in distilled, deionized water, there was no indication of contamination derived from the sampler materials. The diffusion-sampler concentrations were not compared to the concentrations in the original well water used to fill the carboys. The volumes of water varied among the carboys, and the concentrations in the original water were effectively diluted an unknown amount by the water in the samplers. Therefore, the valid comparison was between the water in the carboys and the water in the diffusion samplers at the end of the test.

\section{Pumped and Diffusion Samples from the Monitoring Wells}

The concentrations of perchlorate, RDX, HMX, and other minor explosive compounds in the diffusion and pumped samples collected from the monitoring wells during the field tests mostly were in close agreement (table 4). Only results for compounds detected in at least one sample are shown in table 4 . The concentrations for the diffusion samples were compared to the concentrations for pumped samples collected on one or two pumped-sampling dates nearest the diffusionsampling date. The diffusion samplers were left in the wells for an equilibration period of 42 to 52 days, which was substantially longer than the 19-day equilibration period for the laboratory tests.

The concentrations in the pumped and diffusion samples for the contaminants of greatest interest - perchlorate, RDX, and HMX - are compared graphically in figure 4. Concentrations below the reporting limit were plotted as values of $0.1 \mu \mathrm{g} / \mathrm{L}$ (zero values cannot be shown on a logarithmic scale). If the diffusion and pumped sampling methods produced samples with equal concentrations, all the points on the graphs would fall on the 1:1 lines. The finding that most of the points fell close to the lines indicated that the results from the diffusion samples were comparable to the results from the pumped samples. There is no evidence of a systematic bias in the concentration differences on the basis of type of contaminant or concentration level. This finding contrasts with the observation by Archfield and LeBlanc (2005) of a small systematic bias toward lower concentrations of trichloroethene (TCE) and tetrachloroethene (PCE) in diffusion samples compared to pumped samples.

The good agreement was observed at different concentration levels, as illustrated in figures $5 \mathrm{~A}, \mathrm{C}$, and D for wells with low (MW-100M1), intermediate (MW-143M1), and high (MW-114M2) contaminant levels, respectively. The good agreement also was observed during two separate sampling events at wells MW-100M1 (figs. 5A and B) and MW-143M1 (table 4). This finding is similar to the observation by
Archfield and LeBlanc (2005) of a consistent degree of agreement between the methods for a given well.

For several wells, the agreement between concentrations for pumped and diffusion samples was poorer than the generally close agreement observed at most of the wells. The data for these wells plotted substantially off the 1:1 lines of exact agreement shown in figure 4 . Wells characterized by poor agreement between the methods include MW-165M2, MW-289M2, MW-31M, and MW-76M2 (table 4). None of these wells was tested a second time, so it is unknown if the poor agreement was characteristic of the wells or was a onetime anomalous result.

\section{Factors Affecting Agreement Between the Methods}

The differences in concentrations observed for the pumped and diffusion samples for several wells (table 4) were partly explained by the time lag between collection of the pumped and diffusion samples, particularly for wells in which concentrations were changing rapidly with time. For example, pumped samples were collected from well MW-165M2 at 54 days before and 62 days after collection of the diffusion sample. During this time period, concentrations of perchlorate, RDX, and HMX were decreasing rapidly (fig. 6). As a result, concentrations in the diffusion sample were substantially lower than the concentrations in the first pumped sample (fig. 5E) and substantially higher than the concentrations in the second pumped sample (fig. 5F). Temporal changes in groundwater concentrations also may be factors in the generally poor agreement between sampling methods at wells MW-289M2 and MW-76M2.

Even for samples collected on or about the same day, concentrations that are changing with time could affect the degree of agreement between the methods. Concentrations in pumped samples, which are collected by using low-flow methods, represent concentrations near the well screen at the time of sampling. Concentrations in the diffusion samples, which rely on chemical diffusion through the sampler membrane, represent concentrations in the ground water passing through the well screen during the equilibration period. The diffusion-sample concentration is most strongly influenced by concentrations near the end of the equilibration period; therefore, the concentration differences between samples collected on or about the same day would potentially be greatest when ground-water concentrations are changing rapidly.

The concentrations in both types of samples also may be affected by various hydraulic and chemical factors at the wells, including well construction, chemical and geological heterogeneity near the well screen, and fluid circulation within the wellbore during and between sampling events. For example, concentrations can vary considerably over long screened intervals (Reilly and LeBlanc, 1998), and fluid can circulate vertically inside long screens during and between sampling events (Church and Granato, 1996; Vroblesky and 


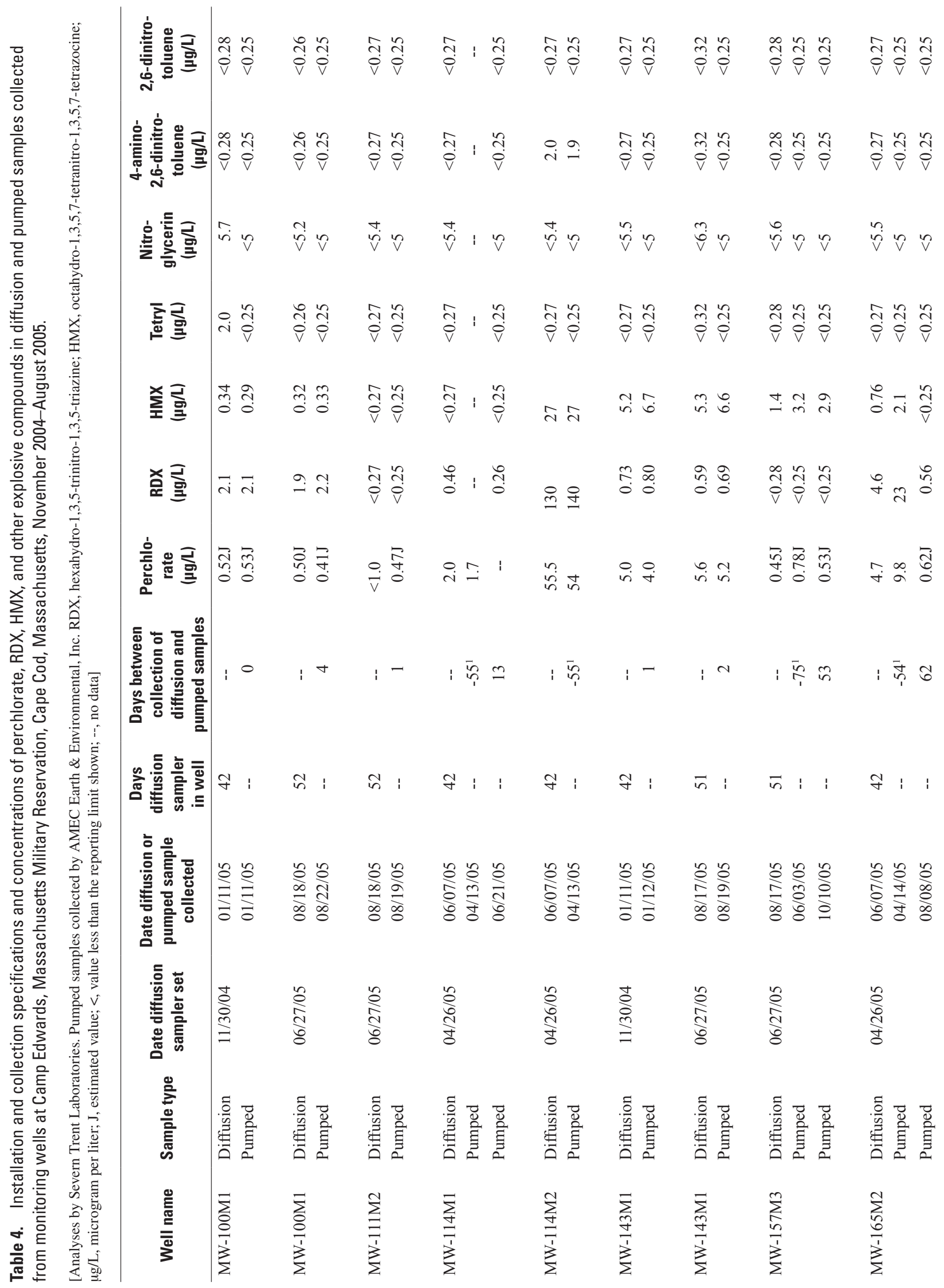




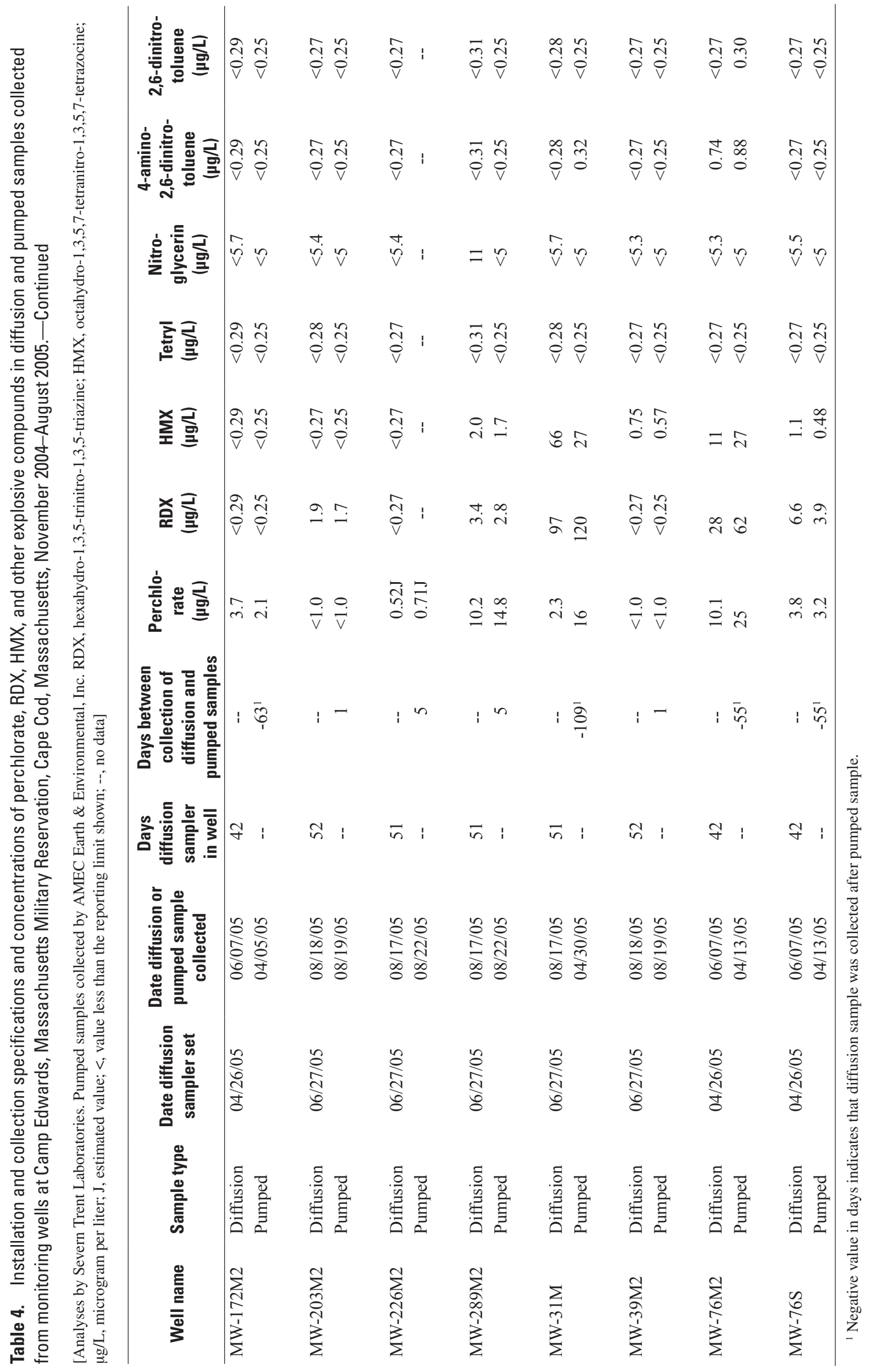


others, 2007). The concentration variations and vertical flow may complicate direct comparison between pumped and diffusion sampling methods. Archfield and LeBlanc (2005) report that the degree of agreement between the sampling methods for VOCs in wells at the MMR was better in wells with 2-ft-long screens than in wells with 5-ft-long screens. Huffman (2002), Church (2000), and Vroblesky (2001b) report, however, that VOC concentrations in diffusion samples collected from wells with screens longer than $5 \mathrm{ft}$ agreed well with concentrations in pumped samples from the wells. In the present study, water from diffusion samplers set at four intervals along the 10 -ft-long well screens was blended to provide sufficient volume for the chemical analyses, and at least one screen volume was purged to waste during pumped sampling prior to sample collection (John Ehret, U.S. Army Corps of Engineers, oral commun., 2008). The sampling methods may have effectively averaged concentration variations along the well screens and improved the comparability of the two types of samples.

During this study, concentrations of perchlorate and explosive compounds in samples collected from two monitoring wells by diffusion and pumped sampling methods agreed closely in two separate sampling events. Archfield and LeBlanc (2005) report that, on the basis of a larger number of wells with multiple sampling events, the degree of agreement of VOC concentrations in pumped and diffusion samples was repeatable for a given well, although they were unable to determine which well-construction or aquifer characteristics affected the degree of agreement. They recommend that a onetime well-by-well comparison between pumped and diffusion sample results could determine which wells are good candidates for the use of diffusion samplers. A similar approach could be used to determine the applicability of the diffusion sampling method for long-term monitoring of perchlorate and explosive compounds near the Impact Area at the MMR.

\section{Limitations of Study and Suggestions for Future Investigations}

The concentrations of the ordnance-related compounds in the pumped and diffusion samples were compared qualitatively in this study because too few wells were sampled to enable comparison of concentrations by statistical methods. The comparison also was complicated by the large variation in time lags between collection of the pumped and diffusion samples. The small sample size and sampling time lags resulted from the limited scope of this initial assessment and the logistical considerations associated with working in a military training area. Future studies could include sample collection from a larger number of wells to allow data analysis by the statistical methods used by Archfield and LeBlanc (2005) to examine diffusion sampling at the MMR for VOCs. Shorter time lags between collection of the diffusion and pumped samples may aid in identifying wells appropriate for long-term monitoring of ordnance-related compounds at the MMR by diffusion sampling methods.

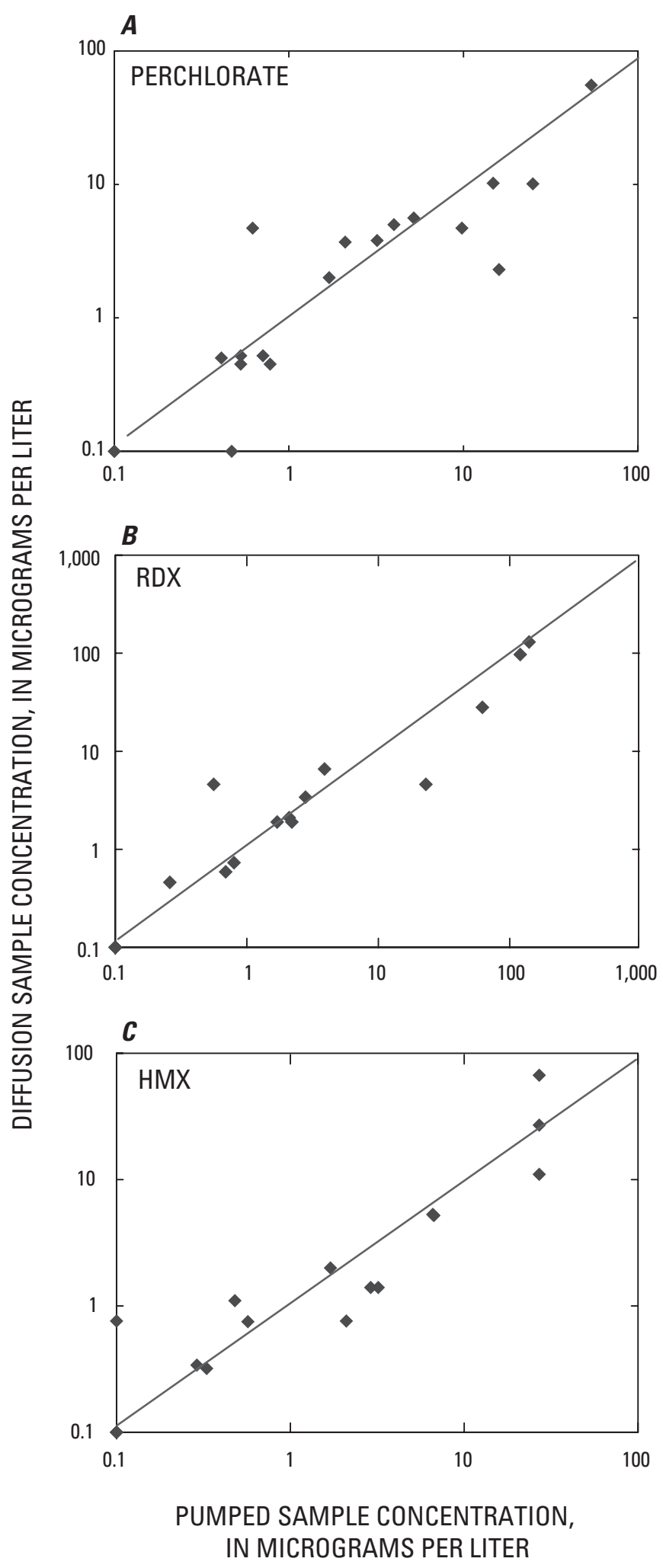

Figure 4. Comparison of $(A)$ perchlorate, $(B) \operatorname{RDX}$, and $(C) H M X$ concentrations for pumped and diffusion samples collected from 15 wells, including two replicate samples, near the Impact Area at Camp Edwards on the Massachusetts Military Reservation, Cape Cod, Massachusetts, 2005. 

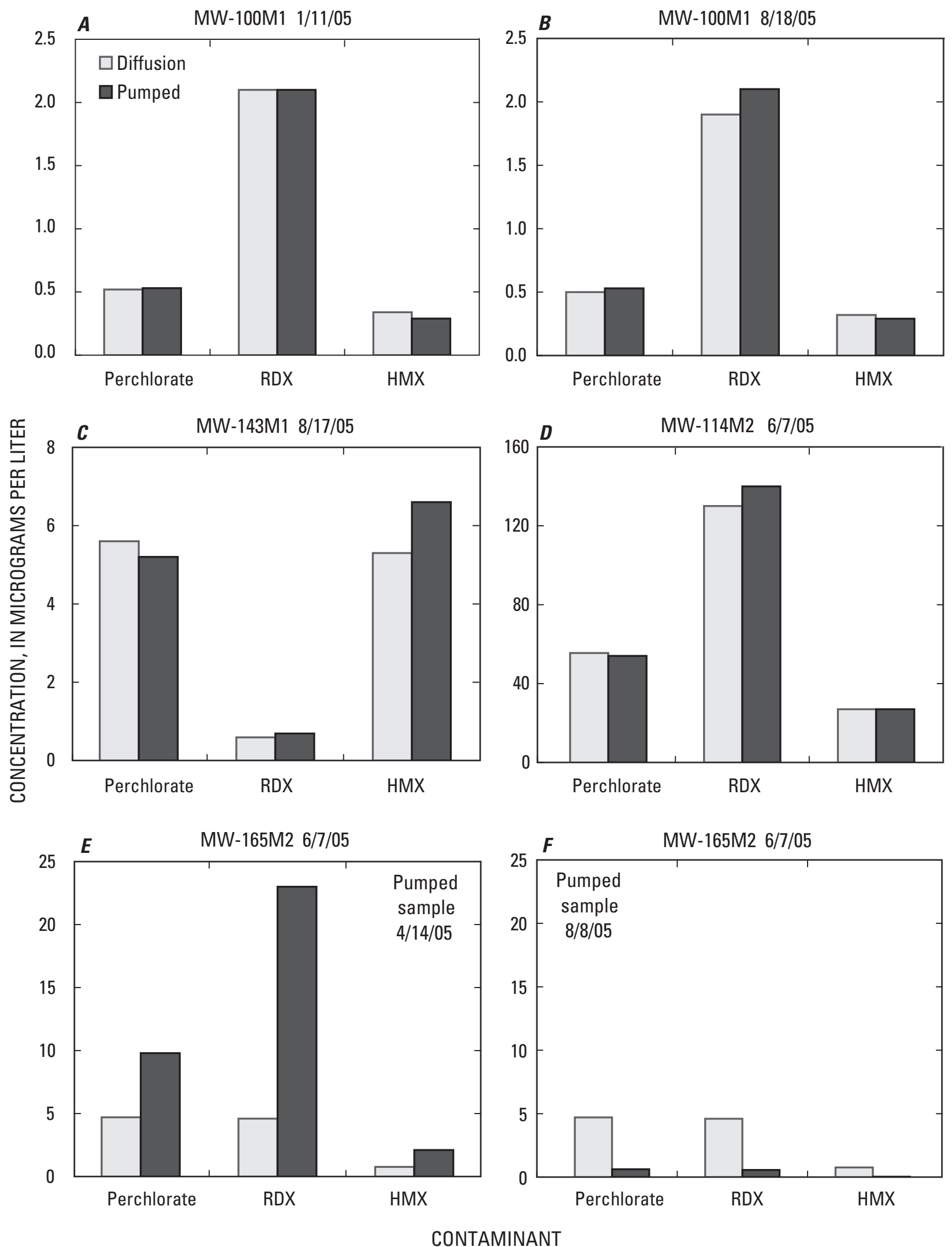

Figure 5. Comparison of perchlorate, RDX, and HMX concentrations for pumped and diffusion samples collected from selected wells near the Impact Area at Camp Edwards on the Massachusetts Military Reservation, Cape Cod, Massachusetts, 2005. (Note different $\mathrm{Y}$-axis concentration scales.) 

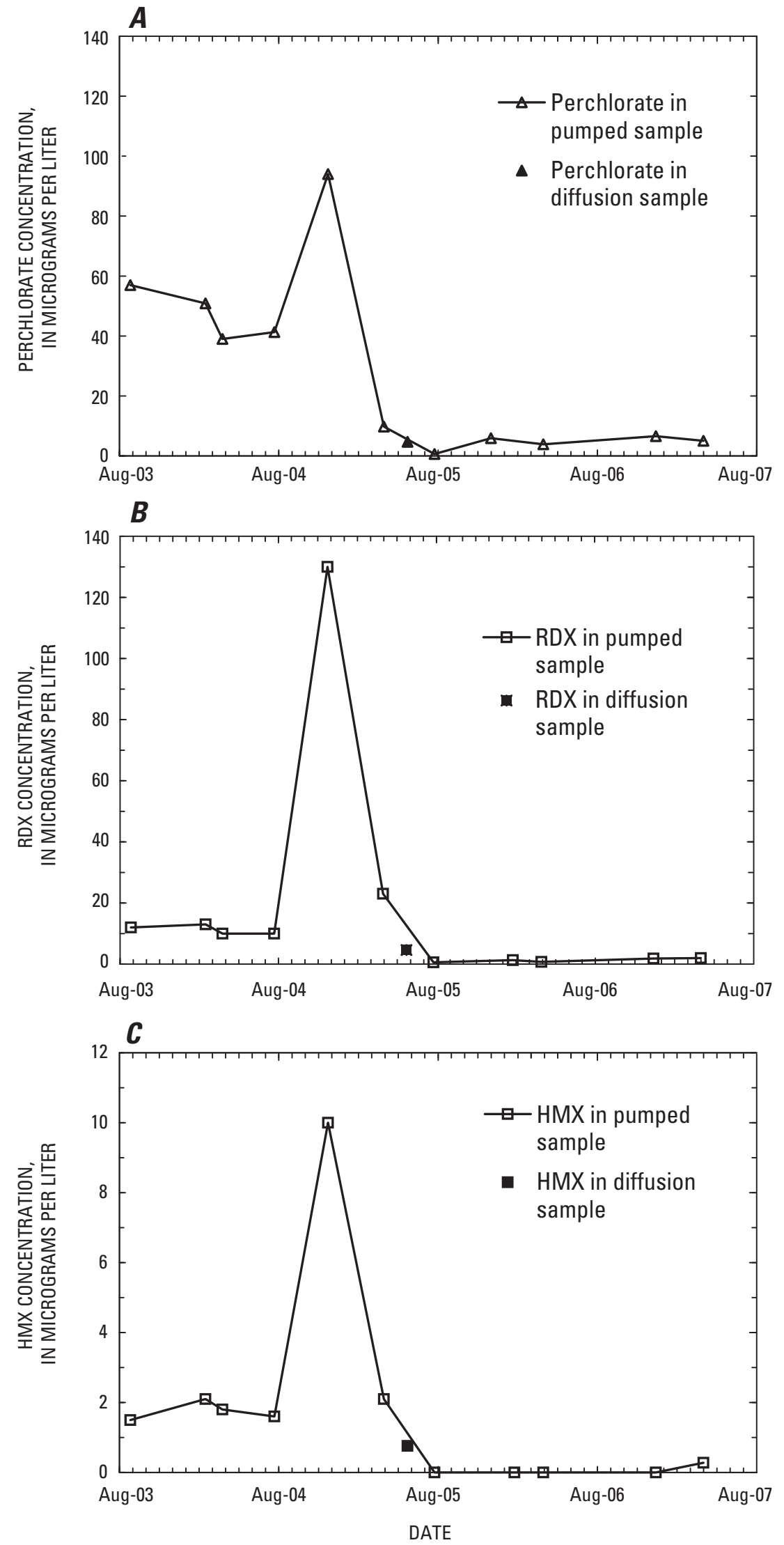

Figure 6. Time history of $(A)$ perchlorate, (B) RDX, and (C) HMX concentrations for pumped and diffusion samples collected from monitoring well MW-165M2 at Camp Edwards on the Massachusetts Military Reservation, Cape Cod, Massachusetts, August 2003 to August 2007. 


\section{Summary}

Long-term monitoring of water quality is an important part of ground-water remediation efforts. Most monitoring programs include regular collection by pumped sampling methods of ground-water samples from a network of monitoring wells. The costs of monitoring can be substantial. In addition, the monitoring process can require disposal of contaminated water produced during well purging prior to sample collection and can cause damage to the local environment by repeated visits to the well sites by field crews and their equipment and vehicles. Passive diffusion sampling is an alternative to pumped sampling that may offer the advantages of lower cost, no production of purge water, and lessened adverse impacts at well sites.

In this study, laboratory and field tests were done to determine the utility of the passive diffusion sampling method for monitoring concentrations of perchlorate and explosive compounds in wells near the Impact Area at Camp Edwards on the Massachusetts Military Reservation on Cape Cod. The sand and gravel aquifer at this site has been contaminated by historical use, testing, and disposal of military ordnance. The contaminant plumes emanating from the site are presently (2008) being remediated by the Impact Area Groundwater Study Program of the U.S. Army Environmental Command, the cooperating agency for this study.

The diffusion samplers tested during this study were constructed of 1-in.-diameter, 7-in.-long sections of rigid, porous polyethylene tubing (6- to $15-\mu \mathrm{m}$ pore size) filled with distilled, deionized water. Laboratory tests of the diffusion samplers were conducted by submerging the samplers in test chambers that were filled with ground water collected from monitoring wells containing various concentrations of perchlorate, RDX, and HMX. The results of the laboratory tests indicate that concentrations of perchlorate and explosive compounds in the water inside the diffusion samplers had equilibrated with concentrations in the water surrounding the samplers in the test chambers by the end of the 19-day-long test period.

Field tests of the diffusion sampling method were conducted in 15 wells near the Impact Area. Four diffusion samplers were set in each well screen for equilibration periods of 42 to 52 days. The wells were constructed of 2- or 2.5-in.-diameter PVC and had 10-ft-long screens. The water from the four diffusion samplers was blended together to produce sufficient volumes for laboratory analysis. For comparison, water samples were collected from the wells by low-flow pumped sampling methods either before or after the diffusionsampler tests. Most wells had close agreement between concentrations of perchlorate, RDX, and HMX in samples collected by diffusion and pumped sampling methods. There was no apparent systematic bias in the concentration differences between the methods related to contaminant type or concentration levels. For several wells, substantial differences between concentrations for the pumped and diffusion samples were related to changing concentrations in the ground water coupled with time lags from 0 to 109 days between collection of the pumped and diffusion samples. Earlier studies report that the degree of agreement between the methods may be a consistent characteristic of the individual monitoring wells, although too few wells were sampled during this study to examine this hypothesis for the ordnance-related compounds.

The results of the laboratory and field tests indicate that passive diffusion sampling may be a useful method for long-term monitoring of concentrations of perchlorate and explosive compounds in wells at the MMR and in similar hydrogeologic settings. One-time well-by-well comparisons between pumped and diffusion sampling results could be used to determine which wells are good candidates for the use of the diffusion sampling method.

\section{Acknowledgments}

The authors thank Andrew Massey, Jennifer Savoie, Megan Chaisson, Jonathan King, Jessica Cochrane, David Robison, and Nicholas Geboy of the USGS, and Shirley Rieven, Timothy Dwyer, and Thomas Remmers of AMEC Earth \& Environmental, Inc., for their assistance in planning and conducting the field effort. The authors also thank Mark Zimmerman and Thomas Imbrigiotta of the USGS for their reviews of this report and Benjamin Gregson for coordinating the IAGWSP support of the project.

\section{References Cited}

Air Force Center for Engineering and the Environment, 2007, Groundwater plume maps \& information booklet: Cape Cod, Mass., Massachusetts Military Reservation, Air Force Center for Engineering and the Environment, 36 p., accessed January 18, 2008, at http://www.mmr.org/2007_ booklet.htm

Air Force Center for Environmental Excellence, 2005, Ashumet Valley SPEIM chemical monitoring network optimization, final project note: Otis Air National Guard Base, Mass., 4P-F41624-03-D-8595, prepared by CH2MHill, Inc., for AFCEE/MMR Installation Restoration Program, July 12, 2005, variously paged.

Archfield, S.A., and LeBlanc, D.R., 2005, Comparison of diffusion- and pumped-sampling methods to monitor volatile organic compounds in ground water, Massachusetts Military Reservation, Cape Cod, Massachusetts, July 1999-December 2002: U.S. Geological Survey Scientific Investigations Report 2005-5010, 53 p. 
Church, P.E., 2000, Evaluation of a diffusion sampling method for determining concentrations of volatile organic compounds in ground water, Hanscom Air Force Base, Bedford, Massachusetts: U.S. Geological Survey Water-Resources Investigations Report 00-4242, 20 p.

Church, P.E., and Granato, G.E., 1996, Bias in groundwater data caused by well-bore flow in long-screen wells: Ground Water, v. 34, no. 2, p. 262-273.

Ehlke, T.A., Imbrigiotta, T.E., and Dale, J.M., 2004, Laboratory comparison of polyethylene and dialysis membrane diffusion samplers: Ground Water Monitoring \& Remediation, v. 24 , no. 1, p. 53-59.

Huffman, R.L., 2002, Comparison of passive diffusion bag samplers and submersible pump sampling methods for monitoring volatile organic compounds in ground water at Area 6, Naval Air Station Whidbey Island, Washington: U.S. Geological Survey Water-Resources Investigations Report 02-4203, 24 p.

Interstate Technology \& Regulatory Council, 2008, Diffusion/ passive samplers: Washington, D.C., accessed February 18, 2008, at http://www.itrcweb.org/teampublic_DPS.asp

LeBlanc, D.R., 2003, Diffusion and drive-point sampling to detect ordnance-related compounds in shallow ground water beneath Snake Pond, Cape Cod, Massachusetts, 2001-02: U.S. Geological Survey Water-Resources Investigations Report 03-4133, 20 p.

LeBlanc, D.R., Guswa, J.H., Frimpter, M.H., and Londquist, C.J., 1986, Ground-water resources of Cape Cod, Massachusetts: U.S. Geological Survey Hydrologic Investigations Atlas 692, 4 sheets, scale 1:48,000.

Massachusetts National Guard (MANG), 2008a, State of the reservation report, training year 2007: Camp Edwards, Massachusetts Military Reservation, Massachusetts National Guard Environmental \& Readiness Center, 90 p.

Massachusetts National Guard (MANG), 2008b, MMR history: Camp Edwards, Massachusetts Military Reservation, Massachusetts National Guard Environmental \& Readiness Center, accessed January 18, 2008, at http://www.mass.gov/ guard/ E\&RC/mmrhistory1.htm

National Research Council, 2000, Natural attenuation for groundwater remediation: Washington, D.C., National Academy Press, 274 p.

Nielsen, D.M., and Nielson, G.L., 2006, Ground-water sampling, in Nielsen, D.M., ed., Practical handbook of environmental site characterization and ground-water monitoring: Boca Raton, Fla., CRC Press, p. 959-1112.

Oldale, R.N., 1992, Cape Cod and the Islands-The geologic story: East Orleans, Mass., Parnassus, 208 p.
Parsons, 2005, Results report for the demonstration of no-purge groundwater sampling devices at former McClellan Air Force Base, California: Denver, Colo., Parsons, prepared for U.S. Army Corps of Engineers Omaha District, Air Force Center for Environmental Excellence, and Air Force Real Property Agency, Contract No. F4465099-D-0005, variously paged.

Reilly, T.E., and LeBlanc, D.R., 1998, Experimental evaluation of factors affecting temporal variability of water samples obtained from long-screened wells: Ground Water, v. 36 , no. 4 , p. 566-576.

Sara, M.N., 2006, Ground-water monitoring system design, in Nielsen, D.M., ed., Practical handbook of environmental site characterization and ground-water monitoring: Boca Raton, Fla., CRC Press, p. 517-572.

Savoie, J.G., LeBlanc, D.R., Blackwood, D.S., McCobb, T.D., Rendigs, R.R., and Clifford, Scott, 2000, Delineation of discharge areas of two contaminant plumes by use of diffusion samplers, Johns Pond, Cape Cod, Massachusetts, 1998: U.S. Geological Survey Water-Resources Investigations Report 00-4017, $30 \mathrm{p}$.

U.S. Army Environmental Command, 2007a, Generic quality assurance project plan: Camp Edwards, Massachusetts, Impact Area Groundwater Study Program, prepared by Environmental Chemical Corporation (ECC), Inc., draft, November 2007, variously paged.

U.S. Army Environmental Command, 2007b, Impact Area Groundwater Study Program, Investigation and cleanup update: Camp Edwards, Massachusetts Military Reservation, U.S. Army Environmental Command, Fact Sheet 2007-05, 32 p., accessed January 18, 2008, at http://groundwaterprogram. army.mil/community/facts/MMR_Plume_ Book_2007_vFINAL_HiRes.pdf

U.S. Environmental Protection Agency, 1994, Method 8330, Nitroaromatics and nitramines by high performance liquid chromatography (HPLC), accessed July 11, 2003, at http://www.epa.gov/sw-846/pdfs/8330.pdf

U.S. Environmental Protection Agency, 1996, Low stress (low flow) purging and sampling procedure for the collection of ground water samples from monitoring wells: Boston, Mass., U.S. Environmental Protection Agency Region I, Standard Operating Procedure No. GW-0001, revision 2, July 30, 1996, 13 p.

U.S. Environmental Protection Agency, 1999, Method 314.0, Determination of perchlorate in drinking water using ion chromatography, accessed July 11, 2003, at http://www.epa. gov/safewater/methods/pdfs/met314.pdf 
U.S. Environmental Protection Agency, 2007, Method 8321B, Solvent-extractable nonvolative compounds by high-performance liquid chromatography/thermospray/mass spectrometry (HPLC/TS/MS) or ultraviolet (UV), accessed April 19, 2008, at http:/www.epa.gov/sw-846/pdfs/8321b.pdf

Vroblesky, D.A., 2001a, User's guide for polyethylene-based diffusion bag samplers to obtain volatile organic compound concentrations in wells, part 1-Deployment, recovery, data interpretation, and quality control and assurance: U.S. Geological Survey Water-Resources Investigations Report 01-4060, 18 p.

Vroblesky, D.A., ed., 2001b, User's guide for polyethylenebased diffusion bag samplers to obtain volatile organic compound concentrations in wells, part 2-Field tests: U.S. Geological Survey Water-Resources Investigations Report 01-4061, variously paged.

Vroblesky, D.A., and Casey, C.C., 2007, Evaluation of porewater samplers at a drainage ditch, Installation Restoration Site 4, Naval Air Station Corpus Christi, Corpus Christi, Texas, 2005-06: U.S. Geological Survey Scientific Investigations Report 2007-5154, 9 p.

Vroblesky, D.A., Casey, C.C., and Lowery, M.A., 2007, Influence of dissolved oxygen convection on well sampling: Ground Water Monitoring \& Remediation, v. 27, no. 3, p. $49-58$.

Vroblesky, D.A., and Hyde, W.T., 1997, Diffusion samplers as an inexpensive approach to monitoring VOCs in ground water: Ground Water Monitoring \& Remediation, v. 17, no. 3, p. 177-184.
Vroblesky, D.A., Joshi, Manish, Morrell, Jeffrey, and Peterson, J.E., 2003, Evaluation of passive diffusion bag samplers, dialysis samplers, and nylon-screen samplers in selected wells at Andersen Air Force Base, Guam, MarchApril 2002: U.S. Geological Survey Water-Resources Investigations Report 03-4157, 29 p.

Vroblesky, D.A., Petkewich, M.D., and Campbell, T.R., 2002, Field tests of diffusion samplers for inorganic constituents in wells and at a ground-water-discharge zone: U.S. Geological Survey Water-Resources Investigations Report 02-4031, 24 p.

Walter, D.A., and Masterson, J.P., 2003, Simulation of advective flow under steady-state and transient recharge conditions, Camp Edwards, Massachusetts Military Reservation, Cape Cod, Massachusetts: U.S. Geological Survey WaterResources Investigations Report 03-4053, 51 p.

Walter, D.A., and Whealan, A.T., 2005, Simulated water sources and effects of pumping on surface and ground water, Sagamore and Monomoy flow lenses, Cape Cod, Massachusetts: U.S. Geological Survey Scientific Investigations Report 2004-5181, 85 p.

Wiedemeier, T.H., Barden, M.J., Haas, P.E., and Dickson, W.Z., 2006, Designing monitoring programs to effectively evaluate the performance of natural attenuation, in Nielsen, D.M., ed., Practical handbook of environmental site characterization and ground-water monitoring: Boca Raton, Fla., CRC Press, p. 573-637. 
Prepared by the Pembroke Publishing Service Center.

For more information concerning this report, contact:

Director

U.S. Geological Survey

Massachusetts-Rhode Island Water Science Center

10 Bearfoot Road

Northborough, MA 01532

or visit our Web site at:

http://ma.water.usgs.gov 


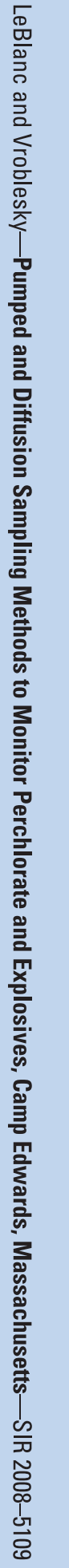

